\title{
Seroprevalence of Salmonella and Mycoplasma gallisepticum Infection in Chickens in Rajshahi and Surrounding Districts of Bangladesh
}

\author{
K. M. Mozaffor Hossain (Corresponding author) \\ Department of Biological Science and Technology \\ Tokyo University of Science, 2641 Yamazaki \\ Noda-Shi, Chiba 278-8510, Japan \\ Tel: 81-4-7124-1501 ext.4425_E-mail: mozaffor03@yahoo.com \\ Md. Takabbar Hossain \\ Upazila Livestock Office, Paba, Rajshahi-6210, Bangladesh \\ Tel: 88-017-1144-3425 E-mail: frabbi_ru@yahoo.com \\ Ichiro Yamato \\ Department of Biological Science and Technology \\ Tokyo University of Science, 2641 Yamazaki \\ Noda-Shi, Chiba 278-8510, Japan \\ Tel: 81-4-7124-1501 ext. 4405 E-mail: iyamato@rs.noda.tus.ac.jp
}

\begin{abstract}
A serological survey on the prevalence of antibodies against Salmonella and Mycoplasma gallisepticum (MG) was carried out in layer chickens in Rajshahi and surrounding districts of Bangladesh. A total of 605 sera samples were examined by rapid plate agglutination (RPA) test using commercial Salmonella and MG antigens to determine the Salmonella and MG specific antibody. Out of 605 sera samples 14.1\% showed single Salmonella, 45.1\% showed single MG and 11.2\% showed their concurrent infection. Prevalence of Salmonella was recorded the highest $(37.6 \%)$ in adult compared to young $(16.7 \%)$. On the contrary, MG and concurrent infections were recorded the highest $(71.7 \%$ and $13.3 \%)$ in young compared to adult $(50.4 \%$ and $10.4 \%)$. The prevalence of Salmonella, MG and concurrent infections were recorded the highest (34.3\%, 68.6\% and 17.1\%) in large flocks compared to small flocks $(21.3 \%, 50.0 \%$ and $8.8 \%)$. The prevalence of Salmonella infection was the highest $(30.4 \%)$ in summer followed by winter $(23.7 \%)$, rainy $(25.0 \%)$ and autumn $(23.3 \%)$. The prevalence of $\mathrm{MG}$ infection was the highest $(61.6 \%)$ in winter followed by autumn $(56.9 \%)$, rainy $(55.0 \%)$ and summer $(49.6 \%)$. Whereas, their concurrent infection was the highest $(12.1 \%)$ in winter followed by summer $(11.9 \%)$, rainy $(10.8 \%)$ and autumn $(10.0 \%)$.
\end{abstract}

Keywords: Seroprevalence, Salmonella, Mycoplasma gallisepticum, Chickens

\section{Introduction}

Salmonellosis is an important disease in chickens caused by Salmonella pullorum and Salmonella gallinarum and is referred to as pullorum disease and fowl typhoid, respectively. Pullorum disease occurs in chicks during their first few days of life and causes severe enteritis and bacteremia (Snoeyenbos et al., 1994). Whereas, fowl typhoid is a disease of mature chickens and causes either acute enteritis with greenish diarrhea or a chronic disease of the genital tract that reduces egg production (Proux et al., 2002). Salmonellosis in poultry causes significant economic loss due to mortality and reduced production (Khan et al., 1998). With the expansion of poultry rearing and farming, pullorum disease and fowl typhoid have become the wide spread problem in Bangladesh (Rahman et al., 1979). Among serological tests, the rapid plate agglutination (RPA) test is very simple, sensitive and used for the detection of Salmonella and MG antibodies under field condition (Avakian et al., 1988). The application of a coordinated policy of hygienic measures together with serological testing and 
slaughter of positive reactors has led to eradication of salmonellosis in many developed countries (Barrow, 1993).

Mycoplasmosis is also an important disease problem in chickens caused by four commonly recognized pathogens namely Mycoplasma gallisepticum, Mycoplasma synoviae, Mycoplasma meleagridis and Mycoplasma iowae (Bradbury, 2001). MG infection is a chronic respiratory disease (CRD) in avian species (Ley, 2003) transmitted both horizontally and vertically and it remains in the flock continuously as a subclinical form (Bencina et al., 1987). It causes decreased feed efficiency, poor carcass quality and sub-optimal egg production in layers (Ley and Yoder, 1997). The infection appears to be world wide spread and can be diagnosed by studying their different properties such as morphological, cultural, biochemical and serological properties of the causal agent (Ley and Yoder, 1997). The control of avian mycoplasmosis by vaccination is limited since only few vaccines are available. Total eradication through test and slaughter is the most effective control method (Yoder, 1991). Therefore, it is important to know the status of salmonellosis, mycoplasmosis and their concurrent infections in chickens to take an effective control measure.

\section{Materials and methods}

This study was conducted at the Department of Animal Husbandry and Veterinary Science, University of Rajshahi, Rajshahi-6205, Bangladesh during the period from January to December 2009. A total of 121 layer chicken flocks were selected in Rajshahi and surrounding districts of Bangladesh.

\subsection{Sampling procedure}

From each flocks five chickens were randomly selected for blood collection. Two ml of blood was collected aseptically from wing vein using sterile syringe and needle. After that syringe with blood was kept in a cool box in a standing position for 6 hours, serum was harvested by decanting. The harvested sera were transferred to 1.5 $\mathrm{ml}$ micro centrifuge tubes and were kept in a cool box before shipping to the laboratory. Sera samples were stored at $-20^{\circ} \mathrm{C}$ in the laboratory until use for RPA test (OIE, 2002).

\subsection{Preparation of antigens}

Antigens are the killed and colored Salmonella and Mycoplasma organisms. Salmonella pullorum antigens from standard (O: 1, 9,12 ${ }_{1}$ and $\left.12_{3}\right)$ and variant (O: 1, 9,12 and 12 2 ) strains were used in this surveillance program for pullorum disease and fowl typhoid (Proux et al., 2002). The MG antigen from an S-6 Adler strain of Mycoplasma gallisepticum organism was used in this surveillance program for avian mycoplasmosis. The Salmonella antigen (Nobilis ${ }^{\circledR} \mathrm{SP}$ ) and MG antigen (Nobilis ${ }^{\circledR} \mathrm{MG}$ ) used in this study were purchased from the Intervet International B.V. Boxmeer-Holland.

\subsection{Rapid plate agglutination (RPA) test}

The RPA test was conducted according to the instructions of OIE Manual (2002). For this test $0.02 \mathrm{ml}$ of antigen and $0.02 \mathrm{ml}$ of chicken serum were placed side by side with micropipettes on a glass plate. Then antigen and serum sample were mixed thoroughly by stirring with a small tooth pick. The glass plate was illuminated from below so as to facilitate observing the reaction, avoiding excessive heat from the light source. Positive reaction was characterized by the formation of definite clumps within 2 minutes after mixing the test serum with antigen (Figure). The clumps usually started appearing and became concentrated at the periphery of the mixture. Negative reaction was judged by the absence of agglutination reaction. Care was taken so that the natural granulation of the antigen showed not to be taken as a positive reaction.

\section{Results and discussion}

\subsection{Overall prevalence of Salmonella and $M G$ infection}

A total of 605 sera samples were collected from 121 commercial layer farms and were subjected to RPA test. Out of these, 85 (14.1\%) were found positive for single Salmonella infection, 273 (45.1\%) were found positive for single MG infection and $68(11.2 \%)$ were found positive for their concurrent infection (Table1). The overall prevalence of Salmonella infection was 25.3\% (14.1+11.2). Similar reports have been described by Alam et al. (2003) who reported 23.8\% seropositive chickens for Salmonella infection in Dinajpur district of Bangladesh. Our finding supports the report of Bouzoubaa et al. (1992) who recorded 23.5\% seropositive chickens for salmonellosis from Morocco. Our percentage (25.3\%) is lower than that of Minga et al. (1987) and Bhattacharya et al. (2001) who reported $33.8 \%$ and $37.7 \%$ seropositive chickens for Salmonella infection in Tanzania and India, respectively. Whereas, Terzolo et al. (1977), Prukner (1987), Ghosh (1988), Muneer et al. (1988), Waltman and Home (1993), Yang et al. (1996), Hasegawa et al. (1999) reported 9.0\%, 13.9\%, 19.6\%, 7.5\%, $15.0 \%, 10.0 \%$ and $16.0 \%$ prevalence of Salmonella infection in chickens, respectively. 
The overall prevalence of MG infection was 56.3\% (45.1+11.2); other species of avian Mycoplasma were not considered in this study. Similar reports were demonstrated by Sikder et al. (2005) who reported 56.9\% seropositive layer chickens for MG infection in Patuakhali district and by Sarkar et al. (2005) who reported $58.9 \%$ seropositive layer chickens for MG infection in some model breeder poultry farms in Feni district of Bangladesh. Our finding also is in agreement with previous reports of Bencina et al. (1987), Godoy et al. (2001), Biswas et al. (2003), Zhang et al. (2001) and Abdu et al. (1983) who reported 56.5\%, 59.1\%, 54.9\%, 53.0\% and $47.5 \%$ seroprevalence of $\mathrm{MG}$ infection in chickens, respectively.

\subsection{Prevalence of Salmonella and $M G$ infection in different ages}

Concerning to the prevalence depending on the ages, the highest prevalence of Salmonella was 37.6\% $(27.2+10.4)$ at 64 weeks and above age group whereas the lowest prevalence was $16.6 \%(3.3+13.3)$ at $16-23$ weeks age group. Similar report was demonstrated by Sikder et al. (2005) who reported the highest Salmonella infection was $30.8 \%$ at 39 weeks of age and the lowest was $13.3 \%$ at 32 weeks of age. Truong et al. (2003) reported that the prevalence of Salmonella infection increased with the increase of age. Whereas, the highest prevalence of MG infection was $71.6 \%(58.3+13.3)$ at $16-23$ weeks age group and the lowest prevalence was $50.4 \%(40.0+10.4)$ at 64 weeks and above age group. Similar report was demonstrated by Sikder et al. (2005) who reported the highest (71.4\%) MG infection at 18 weeks of age and the lowest (55.2\%) at 63 weeks of age. Our finding also supports the report of Sarkar et al. (2005) who recorded 73.8\% MG infection at 20 weeks of age in comparison to $45.2 \%$ at 55 weeks of age. Furthermore, the highest rate of concurrent infection was $13.3 \%$ at 16-23 weeks of age and the lowest was $10.4 \%$ at 64 weeks and above age group (Table 1). The highest rate of concurrent infection in the young chickens is probably due to the highest prevalence of MG infection at this age.

\subsection{Prevalence of Salmonella and $M G$ infection in relation to flock sizes}

Serological investigation showed the highest $(17.1+17.1=34.2 \%)$ Salmonella infection in large flocks $(\geq 5001$ birds) in comparison to small ( $\leq 1000$ birds) flocks $(12.5+8.8=21.3 \%)$. The present data were higher than those in the report of Skov et al. (1999) who recorded 16.8\% Salmonella infection in a flock containing 30-40 thousand chickens in comparison to $11.9 \%$ in a flock containing $10-20$ thousand and $9.7 \%$ in a flock containing less than 10 thousand chickens. Mdegela et al. (2000) recorded higher prevalence of Salmonella infection in commercial flocks $(18.4 \%)$ than in scavenging chickens $(6.3 \%)$ and reported that infection rate increased with the increase of flock size. Similarly, MG infection rate was the highest $(51.4+17.1=68.5 \%)$ in large flocks in comparison to small flocks $(41.3+8.8=50.1 \%)$. Furthemore, concurrent infection was the highest $(17.1 \%)$ in large flocks in comparison to small flocks $(8.8 \%$ ) (Table 2). The highest infection rate in large flocks probably due to faulty in management and bio-security as well as the vertical transmission of the organisms.

\subsection{Seasonal incidence of Salmonella and MG infection}

The prevalence of Salmonalla infection was the highest $(18.5+11.9=30.4 \%)$ in summer followed by winter $(11.6+12.1=23.7 \%)$, rainy $(14.2+10.8=25.0 \%)$ and autumn $(13.3+10.0=23.3 \%)$. Similar report was demonstrated by Rahman et al. (2004) who reported $48.1 \%$ prevalence of Salmonella infection in summer in comparison to $23.7 \%$ in winter. Our finding supports the report of Sikder et al. (2005) who recorded the highest (25.0\%) prevalence of Salmonella infection in rainy season than in winter (21.9\%). Bhattacharjee et al. (1996) reported the highest prevalence of salmonellosis during pre-monsoon (13.1\%) in comparison to winter (10.4\%), monsoon $(6.8 \%)$ and post-monsoon (6.8\%) period. The highest rate of Salmonella infection in summer season is probably due to the high growth rate of bacteria and the influence of hot weather that might reduce the immune status of the birds against infection. Whereas, the prevalence of MG infection was the highest $(49.5+12.1=61.6 \%)$ in winter followed by autumn $(46.9+10.0=56.9 \%)$, rainy $(44.2+10.8=55.0 \%)$ and summer $(37.8+11.9=49.7 \%)$. Similar report was demonstrated by Sarkar et al. (2005) who reported $62.4 \%$ prevalence of MG infection in winter in comparison to $53.1 \%$ in summer. Our finding also supports the report of Sikder et al. (2005) who recorded the highest $(61.5 \%)$ prevalence of MG infection in winter than in rainy $(57.5 \%)$ season. Similarly, the rate of concurrent infection was the highest $(12.1 \%)$ in winter followed by summer $(11.9 \%)$, rainy $(10.8 \%)$ and autumn (10.0\%) (Table 3). The highest rate of concurrent infection in winter is probably due to the highest prevalence of MG infection in that season. From the present study, we have seen that a significant number of birds carry concurrent infection which is more dangerous than single infection. Therefore, it is suggested that the poultry farms should be checked periodically to know the status of Salmonella and MG as well as their concurrent infection. The positive birds should be culled and strict bio-security should be undertaken in order to take an effective control measures. 


\section{References}

Abdu, P. A., Bishu, G., Adysiyun, A. A., \& Adegboye, D. S. (1983). Survey for Mycoplasma gallisepticum and Mycoplasma synoviae antibodies in chickens in Zaria, Nigeria. Journal of Animal Production Research, 3, 63-69.

Alam, J., Koike, I., Giasuddin, M., \& Rahman, M. (2003). Seroprevalence of poultry diseases in native chickens in Bangladesh. Ninth BSVER Annual Scientific Conference, Publication No. 24, pp. 26.

Avakian, A. P., Kleven, S. H., \& Glisson, J. R. (1988). Evaluation of the specificity and sensitivity of two commercial enzyme linked immunosorbent assay kits, the serum plate agglutination test, and haemaglutination inhibition test for antibodies formed in response of Mycoplasma gallisepticum. Avian Diseases, 32, 262-272.

Barrow, P. A. (1993). Salmonella control-past, present and future. Avian Pathology, 22, 651-669.

Bencina, D., Mrzel, I., Tadina, T., \& Dorrer, D. (1987). Mycoplasma species in chicken flocks with different management systems. Avian Pathology, 16, 599-608.

Bhattacharya, A., \& Majumder, P. (2001). Fowl typhoid outbreak in broiler chick flocks in Tripura and its control. Indian Journal of Animal Science, 71, 1034-1035.

Bhattacharjee, P. S., Kundu, R. L., Biswas, R. K., Mazumder, J. U., Hossain, E., \& Miah, A. H. (1996). A retrospective analysis of chicken diseases diagnosed at the Central Disease Investigation Laboratory, Dhaka. Bangladesh Veterinary Journal, 30, 105-113.

Biswas, P. K., Rahman, M. A., Biswas, D., \& Ahmed, S. (2003). A longitudinal study on the prevalence of endemic diseases affecting semi-scavenging poultry reared under PLDP area. Ninth BSVER Annual Scientific Conference, Publication No. 24, pp. 24-25.

Bouzoubaa, K., Lemainguer, K., \& Bell, J. G. (1992). Village chickens as a reservoir of Salmonella pullorum and Salmonella gallinarum in Morocco. Preventive Veterinary Medicine, 12, 95-100.

Bradbury, J. M. (2001). Avian mycoplasmosis. In: Poultry Diseases (pp. 178-193), $5^{\text {th }}$ eds., (Frank Jordan et al., eds.), W. B. Saunders Company, Iowa, USA.

Ghosh, S. S. (1988). Incidence of pullorum disease in Nagaland. Indian Veterinary Journal, 65, 949-951.

Godoy, A., Andrade, L. F., Colmenares, O., Bermudez, V., Herrera, A., \& Munoz, N. (2001). Prevalence of Mycoplasma gallisepticum in egg-laying hens. Veterinary Tropic, 26, 25-33.

Hasegawa, M., Pandey, G. S., Tuchili, L. M., Babe, E., \& Kobayshi, K. (1999). The epidemiology survey of certain poultry diseases in commercial breeding farms in Zambia. International Journal of Animal Science, 14, $17-21$.

Khan, M. A. H. N. A., Bari, A. S. M., Islam, M. R., Das, P. M., \& Ali, M. Y. (1998). Pullorum disease in seminature chicks and its experimental pathology. Bangladesh Veterinary Journal, 32, 124-128.

Ley, D. H. (2003). Mycoplasma gallisepticum infection. In: Diseases of Poultry (pp. 122-144), $11^{\text {th }}$ eds., (Saif, Y. M., Barnes, H. J., Glossons, G. R., Fadly, M. A., McDougald, D. J., \& Swayne, D. E. eds.), Iowa State University Press, Ames, USA.

Ley, D. H., \& Yoder, H. W. Jr. (1997). Mycoplasma gallisepticum infection. In: Disease of Poultry (pp. 194-207), 10 $0^{\text {th }}$ eds., (Calnek, B. W., Barnes, H. J., Beard, C. W., Reid, W. M., \& Yoder, H. W. Jr. eds.), Iowa State University Press, Ames, USA.

Mdegela, R. H., Yongolo, M. G. S., Minga, U. M., \& Olsen, J. E. (2000). Molecular epidemiology of Salmonella gallinarum in chickens in Tanzania, Avian Pathology, 29, 457-463.

Minga, U. M., Kikopa, R., Minja, K. S. G. Z., \& Mwasha, J. D. (1987). The prevalence and improved serodiagnosis of fowl typhoid in Tanzania. Proceedings of the $5^{\text {th }}$ Tanzania Veterinary Association Scientific Conference, Tanzania Veterinary Association, pp. 325-338.

Muneer, M. A., Arhad, M., Sheikh, M. A., \& Ahmad, M. D. (1988). Identification of pullorum disease carriers using spot agglutination test. Pakistan Veterinary Journal, 8, 93-94.

OIE. (2002). Office International Des Epizooties. Manual of Standards for Diagnostic Tests and Vaccines. $4^{\text {th }}$ eds., Paris, France.

Proux, K., Humbert, F., Jouy, E., Houdayer, C., Lalande, F., Oger, A., \& Salvat, G. (2002). Improvements required for the detection of Salmonella pullorum and gallinarum. Canadian Veterinary Research, 66(3), 
151-157.

Prukner, E. (1987). Bacterial infections in the etiology of poultry diseases. Peradarstvo, 22 (11-12), 295-298.

Rahman, M. M., Chowdhury, T. I. M. F., Rahman, M. M., \& Hossain, W. I. M. A. (1979). Surveillance of Salmonella and Escherichia organisms in poultry feed. Bangladesh Veterinary Journal, 15, 59-62.

Rahman, M. A., Samad, M. A., Rahman, M. B., \& Kabir, S. M. L. (2004). Bacterio-pathological studies on salmonellosis, colibacillosis and pasteurellosis in natural and experimental infections in chickens. Bangladesh Journal of Veterinary Medicine, 2(1), 01-08.

Sarkar, S. K., Rahman, M. B., Rahman, M., Amin, K. M. R., Khan, M. F. R., \& Rahman, M. M. (2005). Sero-prevalence of Mycoplasma galliseplicum infection in chickens in model breeder poultry farms of Bangladesh. International Journal of Poultry Science, 4 (1), 32-35.

Sikder, A. J., Islam, M. A., Rahman, M. M., \& Rahman, M. B. (2005). Seroprevalence of Salmonella and Mycoplasma gallisetpticum infection in the six model breeder poultry farms at Patuakhili district in Bangladesh. International Journal of Poultry Science, 4 (11), 905-910.

Skov, M. N., Angen, $\varnothing .$, Chriel, M., Olsen, J. E., \& Bisgaard, M. (1999). Risk factors associated with Salmonella enterica serovar typhimurium infection in Danish broiler flocks. Poultry Science, 78, 848-854.

Snoeyenbos, G. H. (1994). Pullorum disease. In: Diseases of Poultry (pp. 73-86), $9^{\text {th }}$ eds., (Calnek, B. W., Barnes, H. J., Beard, C. W., Reid, W. M., \& Yoder, H. W. Jr. eds.), Iowa State University Press, Ames, USA.

Terzolo, H. R., Verona, A. Z., Furowiez, de. A. J. J. D., \& Verona, De. A. Z. (1977). Finding in fowls Escherichia coli strains having common antigens with the Salmonella genus. Revista-de-la-AssociationArgentina-de-Microbhiologia, 9, 4-10.

Truong, Q., \& Tieu, Q. A. (2003). Prevalence of Salmonella gallinarum and pullorum infection in the Luong Phuong chickens reared in the household sector. Khoa-Hoc-Ky-Thuat-Thu-Y-Veterinary Science and Technology, 10, 15-19.

Waltman, W. D., \& Home, A. M. (1993). Isolation of Salmonella from chickens reacting in the pullorum typhoid agglutination test. Avian Diseases, 37, 805-810.

Yang, Y. C., Sun, Y., Wang, M. M., Zhang, Y. K. Li. X. X., \& Sun, B. A. (1996). Discussion of on site detection of pullorum disease in breeding chickens and control measures. Chinese Journal of Veterinary Medicine, 22, 20-22.

Yoder, H. W. Jr. (1991). Mycoplasma gallisepticum infections. In: Diseases of Poultry (pp. 198-212), $11^{\text {th }}$ eds., (Calnek, B. W., Barnes, H. J., Beard, C. W., Reid, W. M., \& Yoder, H. W. Jr. eds.), Iowa State University Press, Ames, USA.

Zhang, J. H., Wang, D. R. Bi. M. H., Han, B., \& Gao, A. X. (2001). Prevalence and pathogenicity of Mycoplasma gallisepticum in broilers in Inner Mongolia. Chinese Journal of Veterinary Science and Technology, 31, 12-13. 
Table 1. Prevalence of Salmonella and MG infection in different ages

\begin{tabular}{cccccccc}
\hline $\begin{array}{c}\text { Age } \\
\text { (weeks) }\end{array}$ & $\begin{array}{c}\text { No. of } \\
\text { flocks }\end{array}$ & $\begin{array}{c}\text { Single } \\
\text { Salmonella } \\
\text { infection (\%) }\end{array}$ & $\begin{array}{c}\text { Single } \\
\text { Mycoplasma } \\
\text { infection (\%) }\end{array}$ & $\begin{array}{c}\text { Concurrent } \\
\text { infection (\%) }\end{array}$ & $\begin{array}{c}\text { Total } \\
\text { seropositive } \\
(\%)\end{array}$ & $\begin{array}{c}\text { Total } \\
\text { seronegative } \\
(\%)\end{array}$ & $\begin{array}{c}\text { Total tested } \\
\text { sample (N) }\end{array}$ \\
\hline $16-23$ & 12 & $2(3.3)$ & $35(58.3)$ & $8(13.3)$ & $45(75.0)$ & $15(25.0)$ & 60 \\
$24-31$ & 14 & $4(5.7)$ & $38(54.3)$ & $9(12.9)$ & $51(72.9)$ & $19(27.1)$ & 70 \\
$32-39$ & 15 & $7(9.3)$ & $36(48.0)$ & $9(12.0)$ & $52(69.3)$ & $23(30.7)$ & 75 \\
$40-47$ & 13 & $7(10.8)$ & $28(43.1)$ & $7(10.8)$ & $42(64.6)$ & $23(35.4)$ & 65 \\
$48-55$ & 19 & $11(11.6)$ & $39(41.1)$ & $10(10.5)$ & $60(63.2)$ & $35(36.8)$ & 95 \\
$56-63$ & 23 & $20(17.4)$ & $47(40.9)$ & $12(10.4)$ & $79(68.7)$ & $36(31.3)$ & 115 \\
$64-$ above & 25 & $34(27.2)$ & $50(40.0)$ & $13(10.4)$ & $97(77.6)$ & $28(22.4)$ & 125 \\
\hline Total & 121 & $85(14.1)$ & $273(45.1)$ & $68(11.2)$ & $426(70.4)$ & $179(29.6)$ & 605 \\
\hline
\end{tabular}

Table 2. Prevalence of Salmonella and MG infection in relation to flock sizes

\begin{tabular}{|c|c|c|c|c|c|c|c|}
\hline $\begin{array}{l}\text { Flock size } \\
\text { (No. of } \\
\text { birds/flock) }\end{array}$ & $\begin{array}{l}\text { No. of } \\
\text { flocks }\end{array}$ & $\begin{array}{c}\text { Single } \\
\text { Salmonella } \\
\text { infection (\%) }\end{array}$ & $\begin{array}{c}\text { Single } \\
\text { Mycoplasma } \\
\text { infection (\%) }\end{array}$ & $\begin{array}{c}\text { Concurrent } \\
\text { infection } \\
(\%) \\
\end{array}$ & $\begin{array}{c}\text { Total } \\
\text { seropositive } \\
(\%) \\
\end{array}$ & $\begin{array}{c}\text { Total } \\
\text { seronegative } \\
(\%) \\
\end{array}$ & $\begin{array}{l}\text { Total tested } \\
\text { sample (N) }\end{array}$ \\
\hline $500-1000$ & 16 & $10(12.5)$ & $33(41.3)$ & $7(8.8)$ & $50(62.5)$ & $30(37.5)$ & 80 \\
\hline $1001-1500$ & 16 & $9(11.3)$ & $35(43.8)$ & $8(10.0)$ & $52(65.0)$ & $28(35.0)$ & 80 \\
\hline $1501-2000$ & 15 & $10(13.3)$ & $33(44.0)$ & $7(9.3)$ & $50(66.7)$ & $25(33.3)$ & 75 \\
\hline $2001-2500$ & 14 & $9(12.9)$ & $31(44.3)$ & $8(11.4)$ & $48(68.6)$ & $22(31.4)$ & 70 \\
\hline $2501-3000$ & 12 & $8(13.3)$ & $27(45.0)$ & $7(11.7)$ & $42(70.0)$ & $18(30.0)$ & 60 \\
\hline $3001-3500$ & 13 & $10(15.4)$ & $30(46.2)$ & $7(10.8)$ & $47(72.3)$ & $18(27.7)$ & 65 \\
\hline $3501-4000$ & 10 & $8(16.0)$ & $23(46.0)$ & $5(10.0)$ & $36(72.0)$ & $14(28.0)$ & 50 \\
\hline $4001-4500$ & 9 & $7(15.6)$ & $21(46.7)$ & $6(13.3)$ & 34 (75.6) & $11(24.4)$ & 45 \\
\hline $4501-5000$ & 9 & $8(17.8)$ & $22(48.9)$ & $7(16.6)$ & $37(82.2)$ & $8(17.8)$ & 45 \\
\hline 5001-above & 7 & $6(17.1)$ & $18(51.4)$ & $6(17.1)$ & $30(85.7)$ & $5(14.3)$ & 35 \\
\hline Total & 121 & $85(14.1)$ & $273(45.1)$ & $68(11.2)$ & $426(70.4)$ & $179(29.6)$ & 605 \\
\hline
\end{tabular}

Table 3. Seasonal incidence of Salmonella and MG infection

\begin{tabular}{|c|c|c|c|c|c|c|c|}
\hline Seasons & $\begin{array}{l}\text { No. of } \\
\text { flocks }\end{array}$ & $\begin{array}{c}\text { Single } \\
\text { Salmonella } \\
\text { infection (\%) } \\
\end{array}$ & $\begin{array}{c}\text { Single } \\
\text { Mycoplasma } \\
\text { infection (\%) }\end{array}$ & $\begin{array}{c}\text { Concurrent } \\
\text { infection (\%) }\end{array}$ & $\begin{array}{c}\text { Total } \\
\text { seropositive } \\
(\%) \\
\end{array}$ & $\begin{array}{c}\text { Total } \\
\text { seronegative } \\
(\%) \\
\end{array}$ & $\begin{array}{l}\text { Total tested } \\
\text { sample (N) }\end{array}$ \\
\hline $\begin{array}{c}\text { Winter } \\
(\mathrm{Dec}-\mathrm{Feb})\end{array}$ & 38 & 22 (11.6) & $94(49.5)$ & $23(12.1)$ & $139(73.2)$ & $51(26.8)$ & 190 \\
\hline $\begin{array}{c}\text { Summer } \\
\text { (Mar-May) }\end{array}$ & 27 & $25(18.5)$ & $51(37.8)$ & $16(11.9)$ & $92(68.2)$ & 43 (31.9) & 135 \\
\hline $\begin{array}{c}\text { Rainy } \\
\text { (Jun-Aug) }\end{array}$ & 24 & $17(14.2)$ & $53(44.2)$ & $13(10.8)$ & $83(69.2)$ & $37(30.8)$ & 120 \\
\hline $\begin{array}{c}\text { Autumn } \\
\text { (Sep-Nov) }\end{array}$ & 32 & $21(13.1)$ & 75 (46.9) & $16(10.0)$ & $112(70.0)$ & $48(30.0)$ & 160 \\
\hline Total & 121 & $85(14.1)$ & $273(45.1)$ & $68(11.2)$ & $426(70.4)$ & $179(29.6)$ & 605 \\
\hline
\end{tabular}




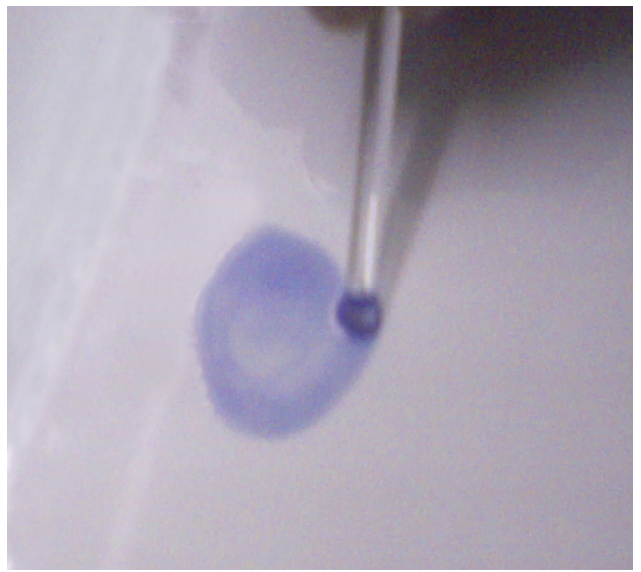

Mixing of antigen with test serum

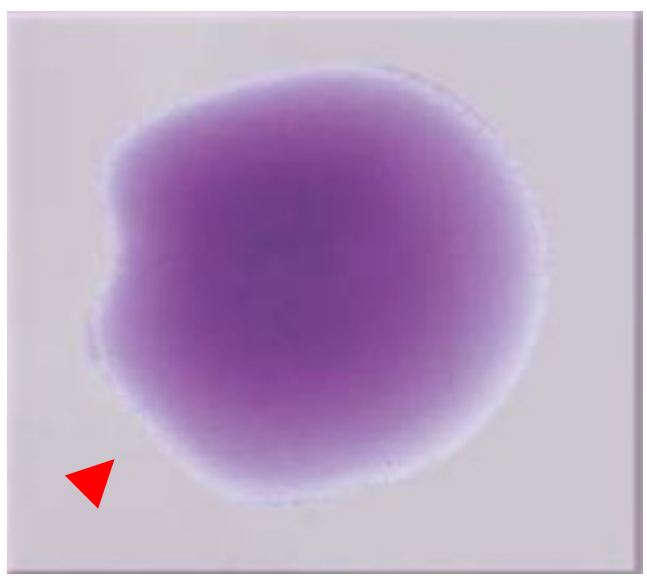

Small clumps, no background clearing $(+)$

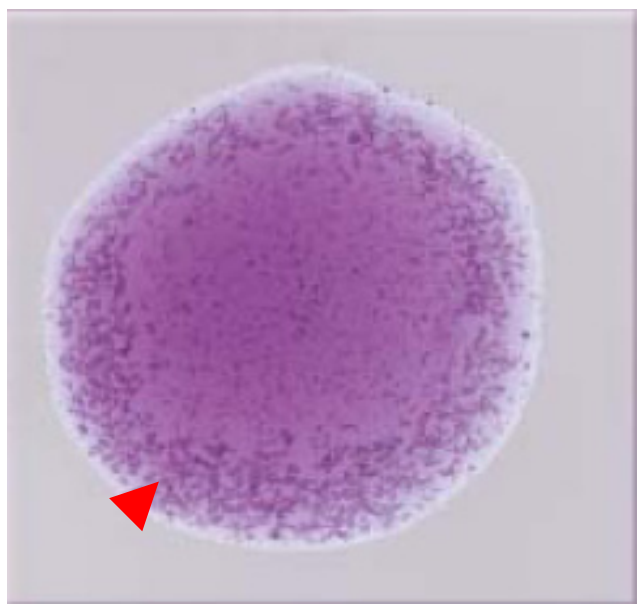

Large clumps, almost complete background clearing $(+++)$

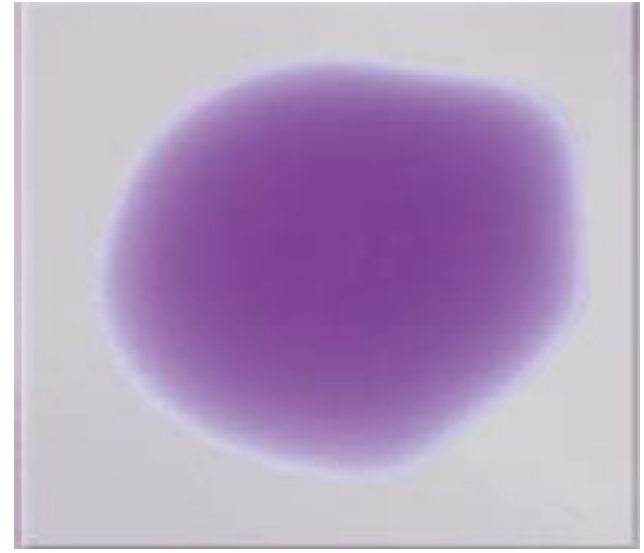

No clumps, no background clearing (-)

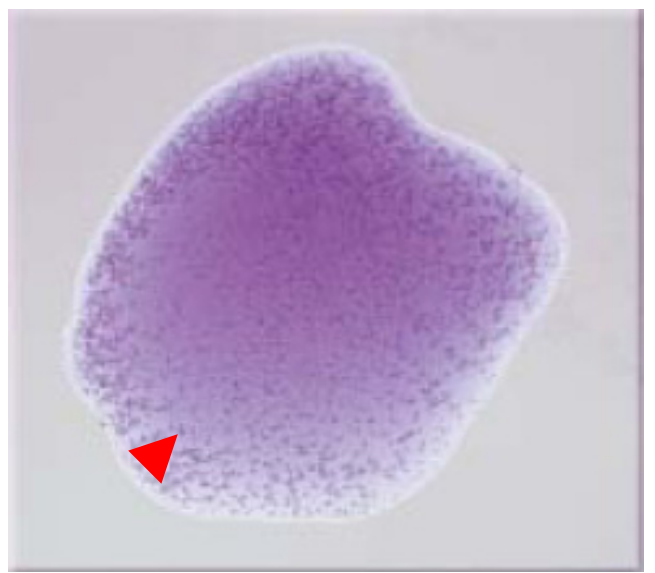

Medium sized clumps almost complete background clearing $(++)$

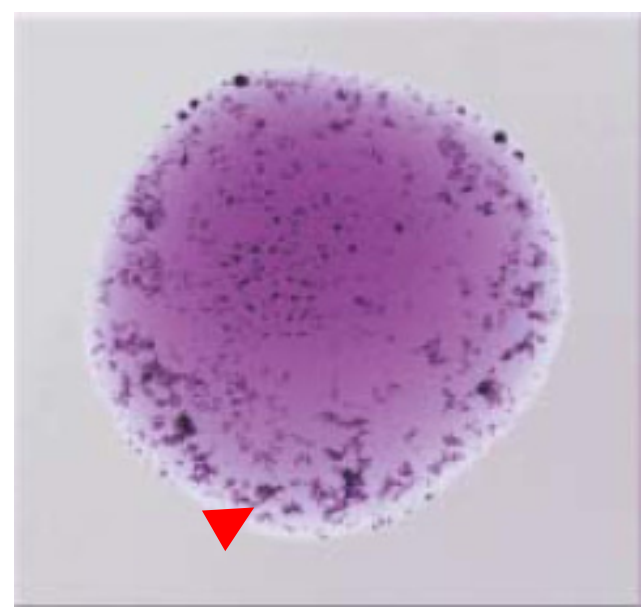

Very large clumps, mostly in the periphery, complete background clearing $(++++)$

Figure. Rapid plate agglutination (RPA) test, arrow indicates the agglutinated particles 